\title{
Climbing behavior of Cordylancistrus sp. in the Colombian Andes
}

\author{
JD Carvajal-Quintero ${ }^{1,2}$, JA Maldonado-Ocampo $^{3 凶}$, A. Urbano-Bonilla $^{1}$
}

\begin{abstract}
The climbing behavior in a suckermouth Loricariidae catfish species is reported for the first time. A group of eight specimens of Cordylancistrus sp. were observed in situ climbing a waterfall in a mountain stream of the Colombian Andes. This study describes how this species overcame the vertical barrier, and then discusses and hypothesizes how the development of "key morphological and behavioral innovations" could play an important role in the occupation of a new niche and in the diversification of the Loricariidae family.
\end{abstract}

Keywords: Loricariidae, key innovations, Colombian Andes

Edited by Alberto Acosta \& Juan Carlos Salcedo-Reyes

1. Laboratorio de Ictiología, Departamento de Biología,

Facultad de Ciencias, Pontificia Universidad Javeriana,

Laboratorio 108B Edf. 53, Bogotá D.C., Colombia.

2 Red de Ecoetología, Instituto de Ecología, A. C., Xalapa,

Veracruz, México.

3 Laboratorio de Ictiología, Unidad de Ecología y Sistemática (UNESIS), Departamento de Biología, Facultad de Ciencias, Pontificia Universidad Javeriana, Laboratorio 108B Edf. 53, Bogotá D.C., Colombia.

Received: 07-10-2014 Accepted: 15-12-2014

Published on line: 26-02-2015

Citation: Carvajal-Quintero JD, Maldonado-Ocampo JA, Urbano-Bonilla A (2015) Climbing behavior of Cordylancistrus sp. in the colombian Andes. Universitas Scientiarum 20(2): 209-215 doi: 10.11144/Javeriana.SC20-2.cbcc

Funding: N/A

Electronic supplementary material: 1

\section{Introduction}

Tropical montane streams are aquatic ecosystems that present diverse challenges to the organisms that inhabit them. Water quality, substrate type, drainage area, diversity in the volume and velocity of the flow, waterfalls, steep gradients, and other movement barriers are some of the factors that determine the composition and structure of the communities in these environments (Jaramillo-Villa et al. 2010, Scatena \& Gutpa 2012, Blanco et al. 2014). To overcome these challenges, native populations have developed diverse morphological and behavioral adaptations, including suitable body shapes for reducing water resistance, suction-cup-like appendages that help them cling to substrate, and the ability to hide under large boulders or reside in shallow water channel-margin habitats during floods and droughts (Maldonado-Ocampo et al. 2005, Scatena \& Gutpa 2012). 
Few fish species can climb waterfalls and thus overcome the geographic isolation that they represent. In streams of Hawaii and other island rivers (rivers characterized by steep slopes, high velocity flow, and high segmentation, Scatena \& Gutpa 2012) juveniles of Gobiidae easily climb falls to avoid predators and reach the habitat occupy by the adults to accomplish recruitment (Keith 2003). They have evolved fused pelvic fins that function as a ventral sucker disc, which allows them to push themselves off against the substrate and move upwards by alternating their ventral attaching with several cycles of axial undulation (Schoenfuss \& Blob 2003, Blob et al. 2006). Similarly, the pacific lamprey [Entosphenus tridentatus (Richardson 1837)] is also able to climb over vertical barriers. This species performs pre-spawning upstream migrations. In the Northwestern United States, hydroelectric dams can impede this species from freely migrating. However, E. tridentatus can sometimes overcome these barriers by attaching to the dam ramps with their sucker mouths and shrinking and straightening their body to propel themselves up (Reinhardt et al. 2008).

In the tropical Andes, tectonic events associated with Andean uplift produced multiple isolated river systems (Lundberg et al. 1998). Today this region contains broad elevational gradients (> $5000 \mathrm{~m}$. in some places) with a rugged topography that creates many breaks in the connectivity (e.g., waterfalls) and marks changes in climatic conditions (Anderson \& MaldonadoOcampo 2010). Together, these factors have created physically and chemically diverse conditions in aquatic environments that have influenced the dispersal of tropical Andean fishes (Maldonado et al. 2010).

Previously, the only reports of climbing behavior in the tropical Andes were related to the catfish family Astroblepidae. Astroblepids are endemic to this region and inhabit streams with high gradients and rapid current (Schaefer \& Arroyave 2010). They are able to move in rapid currents and climb vertical surfaces using their suckermouth and pelvic fins that form an alternating pattern (Johnson 1912, Nelson 2006). Additionally, Astroblepus species possess a duplicated gill opening that allows them to breathe during adhesion (De Crop et al. 2013), and a thickened layer of skin along the ventral surface of the most anterior fin rays of the paired fins; this layer provides them with greater adhesion to the substrate (Conway et al. 2012). This ability to move through steep slopes allows them to inhabit streams at elevations between 1000 and $4000 \mathrm{~m}$ (Schaefer 2003). Although the loricariid fish Lithogenes and the Astroblepids share some of the morphological characteristics associated with climbing (i.e. morphology of the pelvic fins, specialized pelvic musculature; Schaefer \& Provenzano 2008), this behavior is not reported for this fish.

This short communication will report for the first time the climbing behavior of a suckermouth catfish of the family Loricariidae, and discuss the implications that this behavior has on the process of speciation for this family in the Northern Andes.

\section{Materials and methods}

Study area description: The observations were made at a waterfall in Boqueron stream, an Andean tributary of the Rio Bizcocho, Magdalena River Basin (Figure 1). The Boqueron stream is a typical tropical mountain stream, with a steep gradient, reaches with numerous boulders, rapids, and waterfalls that alternate with lower gradient reaches flowing over weathered rock or a thin veneer of coarse alluvium (Wirthmann 2000, Scatena \& Gutpa 2012). The canyon geomorphology of these streams gives them quick hydrologic response times and high runoff that result in high peak discharges during rains. As a result, these mountain streams have seasonal and non-seasonal short-term flooding. They are characterized by a regime where short-term events capable of transporting bedload and removing periphyton occur several times each year (Scatena \& Gutpa 2012). The Boqueron stream reach is bordered by a second-growth Andean forest and is characterized by clear water.

In September 2011, a group of eight individuals of Cordylancistrus sp. (43.4 - $71.6 \mathrm{~mm}$ Standard Length) were observed climbing a waterfall in the main channel of the Boqueron stream. Individuals were first filmed and photographed. Then, two individuals were captured manually for taxonomic identification. Voucher specimens were deposited in the fish collection of the Universidad de Antioquia (CIUA $2100,2101,2102)$ and the film footage was uploaded as supporting information in Suppl. 1. 


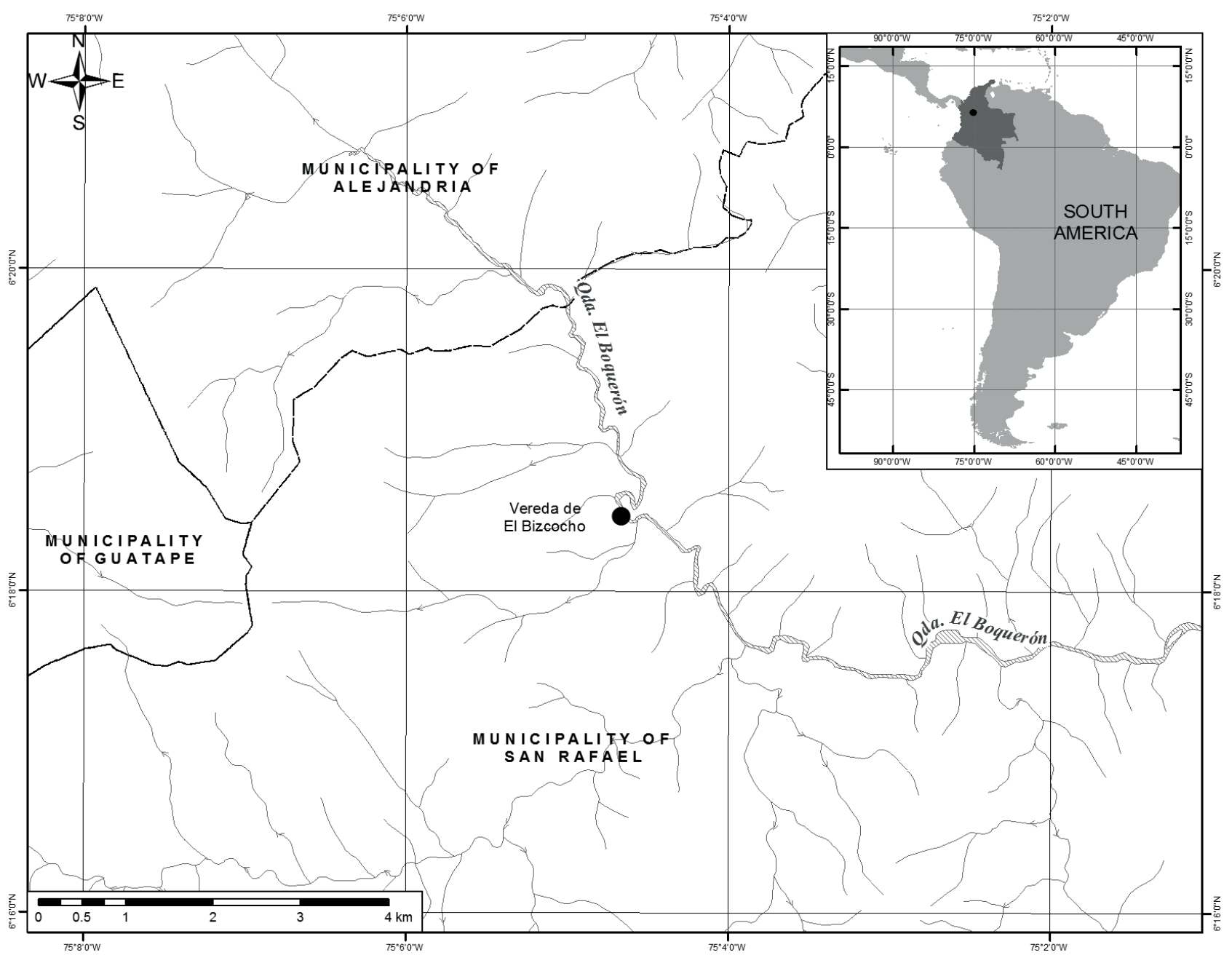

Fig. 1. Map showing the locality (black dot), where Cordilancistrus sp. was observed climbing a waterfall (Boqueron stream, Colombia).

\section{Results and discussion}

The individuals were climbing a waterfall that was $4.53 \mathrm{~m}$ high and had an angle of approximately $84^{\circ}$. It was composed of a large bedrock wall with multiple folds across it. The water flow encompassed the entire channel width of the waterfall, covering the whole wall without leaving any dry sections. However, the flow volume was not homogeneous across the entire width of the waterfall; it was stronger on the left side than on the right (Figure 2).

The group that was observed climbing the waterfall was composed of eight Cordylancistrus sp. It is one of three new species that are being described from the Magdalena-Cauca river basin in Colombia. Cordylancistrus sp., like all Loricariidae, present a specialized ventrally positioned oral disk with flexible edges. This suction cup makes it possible for them to attach firmly to the surface (Lujan \& Armbruster 2012). As documented for other loricariid fish (e.g. Hypostomus), pelvic fins complete the ventral suction mechanisms; they form a triangular suction plate with the bases of these fins that have thickened due to the presence of muscles. These organs (mouth and pelvic fins) create a suction pressure in the belly region that adheres the fish to the substrate and allows it not to be swept downstream despite the considerable force exerted by the flow and gravity. The pectoral fins (that are positioned higher on the body compared to other 


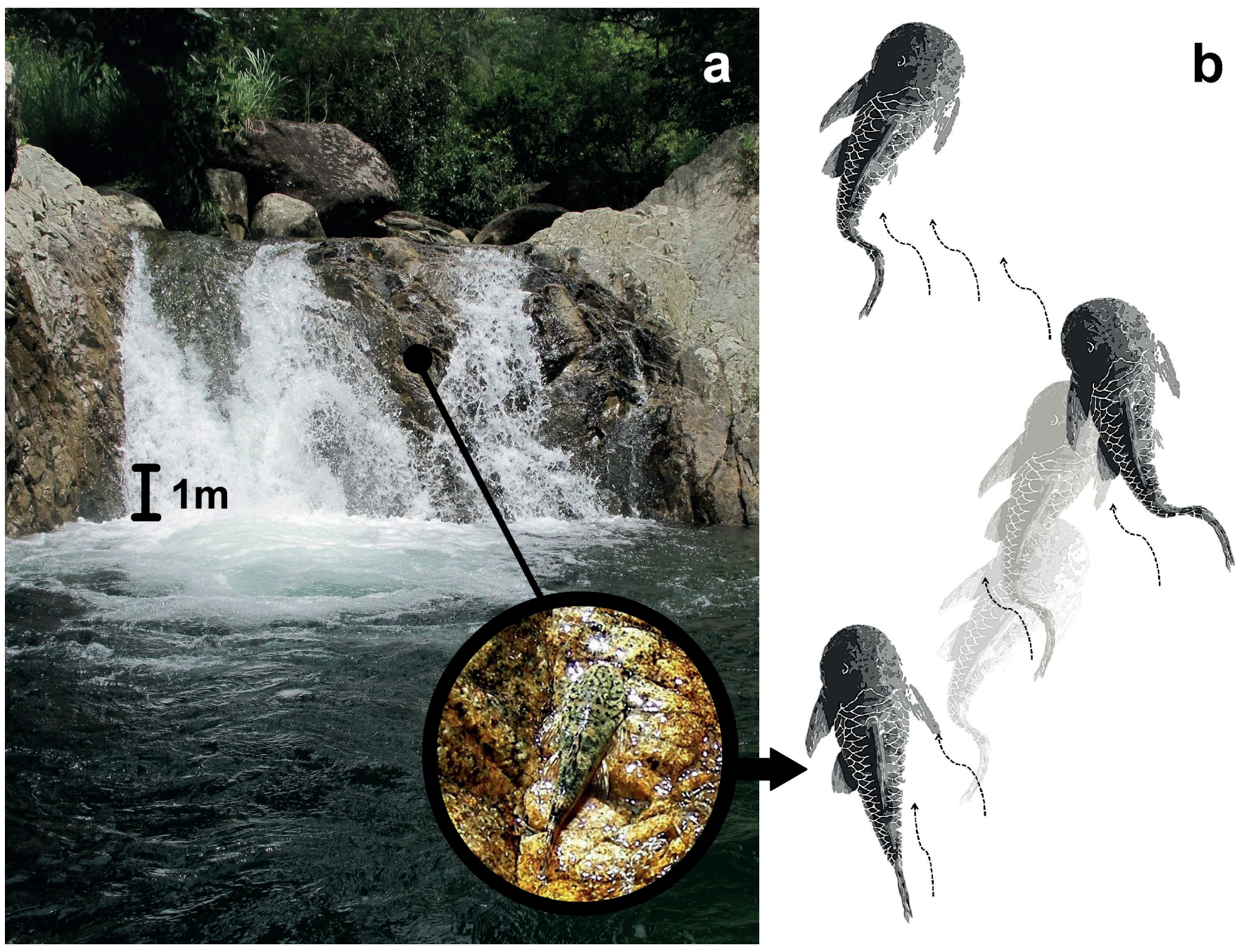

Fig. 2. Climbing behavior adopted by Cordylancistrus sp. a. Place through which individuals of Cordylancistrus sp. climb the waterfall. b. Climbing movements performed for Cordylancistrus sp.

Andean genera of loricariids) have thorn-shaped ossifications along the outer margin of the pectoral spine that allows them to use these fins to laterally fix their position when their flaps are deployed. Additionally, the odontodes present in loricariids increase the friction with the substrate (Gerstner 2007), enhancing their ability to hold their position when their rough lateral surfaces are in contact with the substrate.

By alternating the actions of the mouth and the pelvic, pectoral, and caudal fins, the fish is able to climb the waterfall. The fish begins by adhering itself to the waterfall wall and then retracts the pectoral fins. This is followed by a quick undulation of the body and the caudal fin's ascending of a short transect. Then, it adheres again and redeploys the pectoral fins to remain still for a few minutes. These short ascents are performed in places with less flow volume until they climb the waterfall (Suppl. 1.). However, the technique of passing through regions of shallow water where they encounter less resistance presents a challenge. Since there is a lower flow volume, for most part of the climb the majority of their body will not be fully covered by water making it difficult to breathe.

Survival in a gravity-dominated and aerial environment (i.e. environments where individuals are not fully submerged in the water column) requires numerous physiological and morphological modifications (Daeschler et al. 2006). These adaptations involving modifications that subsequently improve performance 
capacity represent "key morphological and behavioral innovations" (Vermeij 2006) that play an important role in the diversification process (Hunter 1998, Wainwright 2007) and promote ecological opportunity and radiation into new environmental niches (Wainwright 2007, Hoso et al. 2007). Additionally, some studies in stream ecology have found that habitats above waterfalls present lower predation than those sites below waterfalls due to limited predator populations (Covich et al. 2009, Blob et al. 2010). Visual observations (snorkeling across a transect of 100 meters for one hour approximately) performed previously (unpublished data) revealed that upstream of the waterfall, the species Cordylancistrus sp. shares the habitat with species of the genera Astroblepus (detritivores) and Characidium phoxocephalum (Eigenmann 1912) (invertivores). Thus, Cordylancistrus sp. could find refuges lacking predatory fish, and thereby enhance its chances of survival. Climbing behavior has been reported previously for the genera Astroblepus and Characidium (Johnson 1912, Buckup et al. 2000). Although we found no predators upstream of the waterfall, future studies are necessary to confirm that reaches used by the species above waterfalls are predator-free, and that predators are present in downstream reaches.

Future studies of morphology and physiology may improve our understanding of the mechanism that allows Cordylancistrus sp. to climb waterfall environments. These studies should include laboratory experiments to examine the kinematics of vertical locomotion, and microscopic morphological descriptions of the ventral suction organs and the pectoral fins. It is also important to determine which ecological pressures stimulated this species to develop this type of climbing behavior.

\section{Conclusion}

Currently, seven species of the genus Cordylancistrus are recognized and distributed along the northern Andean region, from Ecuador to Venezuela. Four new species descriptions are in progress (including the species reported here), from the Magdalena-Cauca, César, and Ranchería river basins in Colombia. No climbing behavior was previously reported in any suckermouth Loricariidae species, including those of the genera Chaetostoma, Cordylancistrus, Dolichancistrus, and Leptoancistrus, which represent the monophyletic "Chaestostoma" clade (Lujan et al. 2015). This behavior could be present in other species of the "Chaetostoma" group, which have similar morphological adaptations. As it has been hypothesized for the catfish of the family Astroblepidae, this climbing behavior could represent an advantage in the colonization of the upper reaches of streams of the northern Andes. This would facilitate the process of speciation in this region, which has the highest diversity of species of these genera present.

\section{Acknowledgements}

We sincerely thank Dr. Donald C. Taphorn for English proof reading, and five anonymous reviewers and the editor for helpful suggestions that improved this manuscript.

\section{Conflict of interest}

This work does not present any conflicts of interest.

\section{References}

Anderson EP, Maldonado-Ocampo JA (2011) A regional perspective on the diversity and conservation of tropical Andean fishes. Conservation Biology 25: 39-30 doi: 10.1111/j.1523-1739.2010.01568.x

Blanco JF, Escobar-Sierra C, Carvajal-Quintero JD (2014) Gorgona, Baudó y Darién (Chocó Biogeográfico, Colombia): ecorregiones modelo para los estudios ecológicos de comunidades de quebradas costeras. Revista Biología Tropical 62: 43-64

Blob RW, Rai R, Julius ML, Schoenfuss HL (2006) Functional diversity in extreme environments: effects of locomotor style and substrate texture on the waterfall climbing performance of Hawaiian gobiid fishes. Journal of Zoology 268: 315-324 doi: 10.1111/j.14697998.2005.00034.x

Blob RW, Kawano SM, Moody KN, Bridges WC, Maie T et al. (2010) Morphological selection and the evaluation of potential tradeoffs between escape from predators and the climbing of waterfalls in the Hawaiian stream goby Sicyopterus stimpsoni. Integrative \& Comparative Biology 50: 1185-1199 doi: 10.1093/icb/icq070

Buckup PA, Zamprogno C, Vieira F, Teixeira RL (2000) Waterfall climbing in Characidium (Crenuchidae: Characidiinae) from eastern Brazil. Ichthyological Exploration of Freshwaters 11: 273-278 
Conway KW, Lujan NK, Lundberg JG, Mayden RL, Siegel DS (2012) Microanatomy of the paired-fin pads of ostariophysan fishes (Teleostei: Ostariophysi). Journal of Morphology 273: 1127-1149 doi: 10.1002/jmor.20049

Covich AP, Crowl TA, Hein CL, Townsend MJ, McDowell WH (2009) Predator-prey interactions in river networks: comparing shrimp spatial refugia in two drainage basins. Freshwater Biology 54: 450-465 doi: 10.1111/j.13652427.2008.02121.x

Daeschler EB, Shubin NH, Jenkins FA (2006) A Devonian tetrapod-like fish and the evolution of the tetrapod body plan. Nature 440: 757-763 doi: 10.1038/nature04639

De Crop W, Pauwels E, Van Hoorebeke L, Geerinckx T (2013) Functional morphology of the Andean climbing catfishes (Astroblepidae, Siluriformes): Alternative ways of respiration, adhesion, and locomotion using the mouth. Journal of Morphology 274: 1164-1179 doi: 10.1002/jmor.20169

Gerstner CL (2007) Effect of oral suction and other frictionenhancing behaviors on the station-holding performance of suckermouth catfish (Hypostomus spp.). Canadian Journal of Zoology 85: 133-140 doi: 10.1139/z06-199

Hoso M, Asami T, Hori M (2007) Right-handed snakes: convergent evolution of asymmetry for functional specialization. Biology Letters 3: 169-172 doi: 10.1098/ rsbl.2006.0600

Hunter JP (1998) Key innovations and the ecology of macroevolution. Trends in Ecology and Evolution 13: 31-36 doi: 10.1016/S0169-5347(97)01273-1

Jaramillo-Villa U, Maldonado-Ocampo JA, Escobar F (2010) Altitudinal variation in fish assemblage diversity in streams of the central Andes of Colombia. Journal of Fish Biology 76: 2401-2417 doi: 10.1111/j.10958649.2010.02629.x

Johnson RDO (1912) Notes on the habits of a climbing catfish (Arges marmoratus) from the Republic of Colombia. Annals of the New York Academy of Sciences 22: 327-333 doi: 10.1111/j.1749-6632.1912.tb55167.x

Keith P (2003) Biology and ecology of amphidromous Gobiidae of the Indo-Pacific and the Caribbean regions. Journal of Fish Biology 63: 831-847 doi: 10.1046 /j.1095-8649.2003.00197.x

Lujan NK, Armbruster JW, Lovejoy NR, LópezFernández H (2015) Multilocus molecular phylogeny of the suckermouth armored catfishes (Siluriformes: Loricariidae) with a focus on subfamily Hypostominae. Molecular Phylogenetics and Evolution 82: 269-288 doi: 10.1016/j.ympev.2014.08.020

Lujan NK, Armbruster JW (2012) Morphological and functional diversity of the mandible in suckermouth armored catfishes (Siluriformes: Loricariidae). Journal of Morphology 273: 24-39 doi: 10.1002/jmor.11003
Lundberg JG, Marshall LC, Guerrero J, Horton B, Malabarba MC et al. (1998) The stage for Neotropical fish diversification: a history of tropical South American rivers. In: Malabarba LR, Reis RE, Vari RP, Lucena CAS, Lucena ZMS (Ed) Phylogeny and classification of Neotropical fishes. Museu de Ciências e Tecnologia, EPIDUCRS, Porto Alegre, pp 13-48

Maldonado M, Maldonado-Ocampo JA, Ortega $\mathrm{H}$, Encalada AC, Carvajal-Vallejos FM et al. (2010) Diversity in aquatic systems. In: Herzog SK, Martínez $\mathrm{R}$, Jørgensen PM, Tiessen H (Ed) Climate change effects on the biodiversity of the tropical Andes: an assessment of the status of scientific knowledge. IAISCOPE, José dos Campos, pp 325-347

Maldonado-Ocampo JA, Ortega-Lara A, Usma JS, Galvis VG, Villa-Navarro FA et al. (2005) Peces de los Andes de Colombia: guía de campo. Instituto de Investigación de Recursos Biológicos Alexander von Humboldt. Bogotá, DC

Nelson JS (2006) Fishes of the World. John Wiley \& Sons, Inc, New York

Reinhardt UG, Eidietis L, Friedl SE, Moser ML (2008) Pacific lamprey climbing behavior. Canadian Journal of Zoology 86: 1264-1272 doi: 10.1139 / Z08-112

Scatena FN, Gupta A. (2012) Streams of the montane humid tropics. In: Shroder J, Wohl E (Ed.) Treatise on geomorphology, Vol 30 Academic Press, San Diego, pp $1-16$

Schaefer SA (2003) Family Astroblepidae. In: Reis RE, Kullander SO, Ferraris CJ Jr. (Ed) Checklist of the Freshwater Fishes of South and Central America. Edipucrs. Porto Alegre, pp 312-317

Schaefer SA, Provenzano F (2008) The Lithogeninae (Siluriformes, Loricariidae): anatomy, interrelationships, and description of a new species. American Museum Novitates 3637: 1-49 doi.org/10.1206/625.1

Schaefer SA, Arroyave J (2010) Rivers as islands: determinants of the distribution of Andean astroblepid catfishes. Journal of Fish Biology 77: 2373-2390 doi: 10.1111/j.1095-8649.2010.02822.x

Schoenfuss HL, Blob RW (2003) Kinematics of waterfall climbing in Hawaiian freshwater fishes (Gobiidae): Vertical propulsion at the aquatic-terrestrial interface. Journal of Zoology 261: 191-205 doi: 10.1017/S0952836903004102

Vermeij GJ (2006) Historical contingency and the purported uniqueness of evolutionary innovations. Proceedings of the National Academy of Sciences 103: 1804 1809 doi: 10.1073/pnas.0508724103

Wainwright PC (2007) Functional versus morphological diversity in macroevolution. Annual Review of Ecology, Evolution and Systematics 38: 381-401

Wirthmann A (2000) Geomorphology of the Tropics. Springer, Berlin 
Comportamiento de Escalada de Cordylancistrus sp. en los Andes Colombianos

Resumen. El comportamiento de escalada en una especie de bagre Loricariidae con ventosa se reporta por primera vez. Se observó un grupo de ocho especímenes de Cordylancistrus sp. in situ escalando una cascada en un arroyo de montaña de los Andes colombianos. Aquí, describimos cómo esta especie superó la barrera vertical, y finalmente se discute y plantea la hipótesis de cómo el desarrollo de "innovaciones morfológicas y de comportamiento claves" pueden desempeñar un papel importante en la ocupación de un nuevo nicho y en la diversificación de la familia Loricariidae.

Palabras clave: Loricariidae; innovación clave; Andes Colombianos
Comportamento de Escalada de Cordylancistrus sp. nos Andes da Colômbia

Resumo. O comportamento de escalada em uma espécie de cascudo da família Loricariidae é descrita pela primeira vez. Um grupo de oito exemplares de Cordylancistrus sp. foi observado in situ escalando uma cachoeira em um córrego de montanha dos Andes na Colômbia. Neste trabalho, descrevemos como esta espécie ultrapassou a barreira vertical, e finalmente se discute e sugere a hipótese de como as "inovações morfológicas e comportamentais chave" poderiam desempenhar um papel importante na ocupação de um nicho novo e na diversificação da família.

Palavras-chave: Loricariidae; inovação chave; Andes Colombianos 